Reseña

\section{Jerònia Pons Pons y Margarita Vilar Rodríguez. La gestión del seguro de accidentes del trabajo en España: de mutuas patronales a entidades colaboradoras de la Seguridad Social, 1900-2019. Madrid, Ministerio de Inclusión, Seguridad Social y Migraciones, 2020, 388 pp. ISBN: 978-8494889646.}

La historia de las mutuas de accidentes de trabajo en España desde 1900 es el objeto de estudio de este libro, escrito por dos expertas investigadoras en la historia de los seguros y el trabajo en nuestro país en el último siglo. La relevancia del tema estriba, por una parte, en el constante aumento y en la amplitud de personas trabajadoras que están cubiertas por dichas entidades (14 millones de los 19 millones de población activa que había en España en 2017) y, por otra parte, en arrojar luz sobre la complejidad de la evolución de las relaciones entre el sector privado y el Estado en materia de seguros sociales en los últimos 119 años.

La introducción sitúa brevemente la obra en el marco de la historiografía europea sobre la evolución de los diversos modelos de seguros de accidentes de trabajo en el siglo xx, y concentra la atención del trabajo en la evolución del marco normativo y legislativo específico sobre este tipo de seguros, ámbito en el que este libro se constituye en un referente para cualquier estudioso interesado en la progresión de la intervención estatal en un sector en el que se crearon y consolidaron importantes entidades privadas. En este marco de revisión historiográfica, Pons y Vilar señalan con rotundidad que en España existió una implantación comparativamente tardía del intervencionismo estatal en materia laboral, desde finales del siglo xIx y durante la primera década del siglo xx.

El objetivo del libro, analizar de manera novedosa con enfoque de largo plazo el origen y transformación de este tipo de mutuas, en origen denominadas patronales, hasta convertirse en colaboradoras de la Seguridad Social desde 1900, se lleva a cabo fundamentalmente con documentación estadística, informes, anuarios, y diversa bibliografía procedente de archivos del Ministerio de Trabajo e INGESA. Estas fuentes han sido explotadas en cuadros y gráficos que proporcionan abundante información cuantitativa sobre pólizas y primas de centenares de mutuas para distintos períodos que cubren un siglo de historia del sector. Una obra de referencia y, además, muy bien escrita, que complementa estos datos con una fantástica revisión de informes sobre los obstáculos y dificultades en la expansión del seguro de accidentes en nuestro país en distintos sectores de actividad, así como en los distintos territorios del Estado español.

El trabajo se organiza en cuatro capítulos. El primero, sobre los orígenes históricos de las mutuas patronales de accidentes de trabajo surgidas en el ámbito privado industrial tras la Ley de Accidentes de Trabajo o ley Dato de 1900, que no obligó a contratar un seguro, pero sí responsabilizó a los empresarios de los accidentes de sus trabajadores y obligó a indemnizarlos y asistirlos. La II República permitió la extensión del seguro al ámbito agrario en 1931 y a un seguro de accidentes obligatorio para trabajadores del sector industrial, lo que estimuló el crecimiento del sector hasta llegar a alcanzarse 84 mutualidades patronales agrícolas y 157 industriales en 1935. El segundo capítulo, entre la Guerra Civil y 1966, demuestra que a partir de 1955 se introdujeron medidas de racionalización y eliminación de mutuas poco eficiente, y se iniciaron convenios de colaboración con el Estado para gestionar el seguro obligatorio de enfermedad (SOE), establecido en 1942. El tercer capítulo describe el abandono forzado de la gestión en el SOE y la colaboración con la Seguridad Social en el seguro de accidentes de trabajos, con una reorganización de las mutuas por ámbitos de especialización hasta 1975. La transición democrática es el centro del último capítulo, analizándose la intensa concentración que se produjo hasta llegar a una veintena de mutuas en 2019 (desde las 187 existentes en 1976), y los cambios en las funciones de las mutuas, su número y ámbito de actuación.

Jerònia Pons y Margarita Vilar son dos de nuestras historiadoras económicas y empresariales más solventes, y esta obra viene a completar una producción intensa, rigurosa y fundamental, de referencia obligatoria, que han venido llevando a cabo juntas en la última década sobre la historia del seguro en España. Este estudio de largo plazo sobre la transición de mutuas patronales a entidades colaboradoras de la Seguridad Social en la gestión del seguro de accidentes en nuestro país está muy bien documentado, muy bien estructurado, muy bien escrito y con abundancia de aparato estadístico y bibliográfico de apoyo procedente de los archivos del Ministerio de Trabajo e INGESA. El libro refleja muy bien el cambio institucional y el cambio de gestión en un ámbito que nos interesa a todos, no solo como historiadores, sino también como trabajadores.

Paloma Fernández Pérez Universitat de Barcelona

https://doi.org/10.33231/j.ihe.2021.09.009 